\title{
The Changing Face of Spondyloarthropathies Under TNF $\alpha$ Blockade
}

\author{
Ori Elkayam ${ }^{*}, 1,2$, Irena Litinsky², David Levartovsky ${ }^{2}$ and Dan Caspi ${ }^{2}$ \\ ${ }^{I}$ Department of Internal Medicine F and ${ }^{2}$ Rheumatology, Tel Aviv Sourasky Medical Center, The Sackler Faculty of \\ Medicine, Tel Aviv University, Tel Aviv, Israel
}

\begin{abstract}
Objectives: Tumor necrosis factor alpha (TNF- $\alpha$ ) therapy has been implicated in the development of autoimmune diseases. Our aim was to describe three patients with spondyloarthropathies who responded to infliximab, a chimeric monoclonal antibody specific for TNF- $\alpha$, but developed new symptoms of spondyloarthropathies. In parallel, a review of the literature on psoriasis induced by TNF- $\alpha$ blockers was undertaken.

Results: The first patient had been suffering from ankylosing spondylitis (AS) for more than 12 years. Infliximab induced a remission of AS, but he developed overt Crohn's disease two years after starting treatment. The second patient had AS for more than 20 years. Infliximab had an excellent effect on his AS, but he developed palmo-plantar psoriasis a few months after initiating therapy with the drug. The third patient, whose long-term and severe psoriasis had responded to infliximab developed peripheral arthritis. A review of the literature revealed 63 cases of psoriasis induced by TNF- $\alpha$ blockers (33 on Infliximab, 16 on Etanercept and 14 on Adalimumab). The underlying diseases were variable, including all the spectrum of conditions for which TNF- $\alpha$ blockers are indicated. Patients developed psoriasis after a mean duration of treatment of 11 months. Interstingly, a substantial proportion of patients continued treatment with TNF $\alpha$ blockers, the psoriasis improving in a majority of cases under topical treatment only.
\end{abstract}

Conclusion: While Infliximab may change the course of spondyloarthropathy, depressing the original symptoms it may uncover other occult aspects of these diseases.

Keywords: Infliximab, spondyloarthropathy, crohn, psoriasis, anti-TNF $\alpha$.

\section{INTRODUCTION}

Tumor necrosis factor alpha (TNF- $\alpha$ ) is an inflammatory cytokine that has been implicated in a variety of rheumatic and inflammatory diseases [1]. Infliximab, a chimeric monoclonal antibody specific for TNF-alpha, has been approved for the treatment of rheumatoid arthritis, Crohn's disease, ankylosing spondylitis, psoriasis and psoriatic arthritis [1]. In addition to dramatically changing the prognosis of these diseases, the use of infliximab has been associated with the development of a variety of autoimmune diseases such as systemic lupus erythematosus (SLE), vasculitis as well as psoriasis $[2,3]$.

Spondyloarthropathies are a family of related diseases which share striking points of similarity, such as negative tests for rheumatoid factor, absence of subcutaneous rheumatoid nodules, peripheral inflammatory arthritis, radiological sacroiliitis, tendency to familial aggregation, and - notably - a spectrum of overlapping features shared between the individual entities of this group [4]. As such, patients with one manifestation of spondyloarthropathy may develop features of other spondyloarthropathies. We report three cases of patients who suffered from spondyloarthropathy related diseases who responded to treatment with infliximab but developed new manifestations of spondyloarthropathies in

*Address correspondence to this author at the Department of Internal Medicine F and the Rheumatology Institute, Tel Aviv Sourasky Medical Center, 6 Weizmann Street, Tel Aviv 64239, Israel; Tel: 97236973668 ;

Fax:97236974437; E-mail: oribe14@netvision.net.il spite of responding well to therapy, suggesting that TNF- $\alpha$ blockade had stimulated overt manifestation of occult features of their disease.

\section{METHODS}

The three cases are reported with special emphasis on the clinical history and appearance of new symptoms with respect to the use of Infliximab. A Medline database search using the terms "psoriasis infliximab etanercept adalimumab crohn arthritis" between January 1985 and august 2007 was performed.

\section{CASES}

The 3 case reports are summarized in Table $\mathbf{1 .}$

\section{CASE REPORT 1}

The patient, a 33-year-old man, was diagnosed as ankylosing spondylitis in 1995. There was no personal or familial history of psoriasis, inflammatory bowel disease or reactive arthropathy. He had failed several non-steroidal anti-inflammatory drugs (NSAIDs) and sulphasalazine due to lack of efficacy or side effects. He was commenced on low dose infliximab $(3 \mathrm{mg} / \mathrm{kg})$ in June 2005 and experienced an impressive improvement in his complaints. The pretreatment BASDAI score of 7 dropped to 3 and C-reactive protein (CRP) and erythrocyte sedimentation rate (ESR) levels normalized. On February 2007, 2 weeks after the last infusion of infliximab and while he was free of the musculoskeletal complaints, he developed abdominal pain and bloody diarrhea. A colonoscopy performed a few days later revealed 
Table 1. Characteristics of the 3 Patients Reported

\begin{tabular}{|c|c|c|c|c|c|}
\hline & Age/Gender & Disease & Adverse Event & Time to Adverse Event & Outcome \\
\hline \hline Case 1 & $33 / \mathrm{M}$ & AS & Crohn's & 22 months & Resolution with mesalazine, Infliximab continued \\
\hline Case 2 & $46 / \mathrm{M}$ & AS & Psoriasis & 5 months & Resolution after switching to etanercept \\
\hline Case 3 & $46 / \mathrm{F}$ & Psoriasis & Arthritis & 7 months & Resolution after switching to etanercept \\
\hline
\end{tabular}

macroscopic and histological findings typical of Crohn's disease In retrospective he denied any past symptoms of IBD. The patient was treated with Mesalazine with resolution of his symptoms. He subsequently continued treatment with Infliximab at a dosage of $5 \mathrm{mg} / \mathrm{kg}$.

\section{CASE REPORT 2}

A 46-year-old man diagnosed as having ankylosing spondylitis in 1985 . He ultimately developed stiffness of the entire spine, kyphosis of the thoracic spine and ankylosis of the cervical spine, but never experienced any extra-skeletal manifestation of the condition. Despite the advanced anatomical status of the primary disease, activity was evident based on severe inflammatory back pain, the constant need for NSAIDS and increased ESR and CRP levels. In 2006, infliximab was prescribed. After the second infusion, he reported a significant improvement in back pain and morning stiffness, accompanied by a decrease in ESR and CRP levels. Five months after starting this treatment, however, he developed a symmetric erythematous eruption of his palms and soles (Fig. 1) mandating cessation of treatment. Infliximab was exchanged with etanercept resulting in rapid resolution of the rash and excellent effect on symptoms of ankylosing spondylitis.

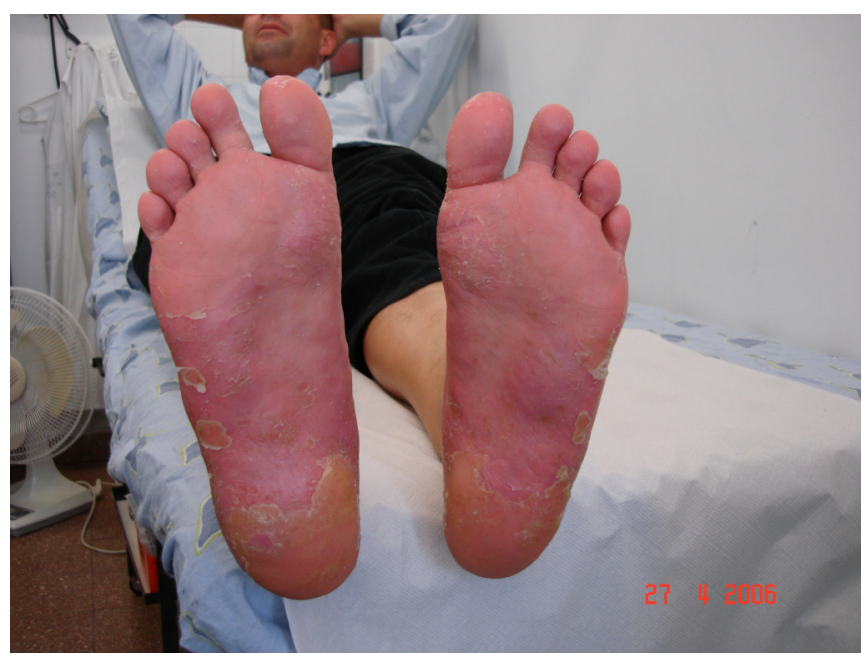

Fig. (1). Plantar psoriasis in patient 2, after treatment with infliximab.

\section{CASE REPORT 3}

A 46-year-old woman, having psoriasis more than 20 years. The condition became progressively severe, and involved more than $70 \%$ of the body most of the time. She had failed topical treatments, methotrexate, cyclosporine, neotigazone and psoralen ultraviolet A (PUVA). Despite the severity of the psoriasis, she never had musculoskeletal complaints. In 2006, she was started on $5 \mathrm{mg} / \mathrm{kg}$ infliximab, with resolution of more than $75 \%$ of the psoriatic lesions. Three weeks after the sixth infusion, she developed arthritis of the small joints of the hands, shoulders and knees, without enthesitis or dactylitis. The laboratory tests revealed an increased ESR and a positive antinuclear factor with normal anti-dsDNA. She nevertheless continued treatment with infliximab, and experienced a significant improvement in both skin and musculoskeletal signs, lasting for 3 weeks after each infusion. Treatment with Infliximab was subsequently stopped and switched to Etanercept.

\section{LITERATURE REVIEW}

A Medline database search of relevant publications in the English literature between January 1985 and august 2007 did not reveal reports of Crohn's disease or psoriatic arthritis following infliximab. However, more than 80 cases of psoriasis in patients treated with TNF- $\alpha$ blockers have been described [2, 3, 5-30]. Table 2 summarizes the clinical characteristics of theses patients. 33 patients were on Infliximab, 16 on Etanercept and 14 on Adalimumab. The underlying diseases were variable, including the whole spectrum of conditions for which TNF $\alpha$ blockers are indicated. Patients developed psoriasis after a mean duration of treatment of 11 months. Table 2 reports the outcome of these patients. Interestingly, a substantial proportion of patients continued treatment with TNF $\alpha$ blockers, the psoriasis improving in a majority of cases under topical treatment only; implicating that cessation of therapy is not always indicated.

\section{DISCUSSION}

Our 3 described patients underwent an impressive resolution of the original symptoms which warranted the administration of infliximab, but each went on to develop new spondyloarthropathic features while under this TNF- $\alpha$ therapy. All 3 patients had a protracted disease before being starting infliximab, without a hint for their eventual postinfliximab additional symptoms, which make it much more likely that their de novo symptoms are related to the effect of the medication.

Several lines of evidence pointing to the immunomodulatory effects of TNF- $\alpha$ blockades have been accumulating with the increasing use and longer follow-up of treatment with TNF- $\alpha$ antagonists. Testimony of autoimmunity triggered by TNF- $\alpha$ blockers includes 92 reported cases of lupus, 113 patients with vasculitis and 24 cases of interstitial lung diseases [2]. The ability of TNF- $\alpha$ to induce autoantibodies in a large proportion of patients was established in several studies [31-33].

Our cases represent untoward immunomodulation triggered by infliximab that had brought about the desired therapeutic effects on the existing disease symptoms for which it had been prescribed. The first case was a patient with long- 
Table 2. Clinical and Demographic Charasteristics of Patients Who Developed Psoriasis Under Treatment with TNF $\alpha$ Blocker

\begin{tabular}{|c|c|}
\hline Gender & 57 Females, 33 Males, 3 UK \\
\hline Mean Age; Range & $45 ; 13-78$ \\
\hline Underlying disease & $\begin{array}{l}44 \text { RA, } 2 \text { JRA,9 Crohn, } 1 \text { UC, } \\
17 \text { AS (+4 Crohn), } 2 \text { Behcet, } \\
1 \text { PsA,1 eosinophilic fasceitis, } 1 \text { uveitis }\end{array}$ \\
\hline Concomitant drugs & $\begin{array}{l}\text { None } 6 \text {, Methotrexate } 22 \text { Prednisone } 8 \text {, } \\
\text { Salazopyrine } 5 \text {, Leflunomide } 8 \text {, } \\
\text { Azathioprine } 3\end{array}$ \\
\hline Infliximab & 47 \\
\hline Etanercept & 17 \\
\hline Adalimumab & 16 \\
\hline Family history of psoriasis & 3 \\
\hline $\begin{array}{l}\text { Mean duration of } \\
\text { treatment until } \\
\text { psoriasis; SD }\end{array}$ & $\begin{array}{l}11 \pm 12 \\
\text { Infliximab: } 9 \pm 10 \\
\text { Etanercept: } 7 \pm 7 \\
\text { Adalimumab: } 16 \pm 19\end{array}$ \\
\hline $\begin{array}{l}\text { Characteristics of } \\
\text { psoriasis }\end{array}$ & 39 PPP, 38 Psoriasis vulgaris, 4 UK \\
\hline
\end{tabular}

standing ankylosing spondylitis who acutely developed Crohn's disease. Endoscopic studies in patients with ankylosing spondylitis have demonstrated the presence of intestinal inflammation in up to $60 \%$ of them, particularly in those with active peripheral joint disease [34]. One prospective follow-up of patients with juvenile onset disease who initially presented with peripheral rather than axial joint disease also showed that intestinal inflammation increases the likelihood of progression to axial disease [35]. Our patient was probably predisposed to develop inflammatory bowel disease, but the fact that it developed with the introduction of infliximab, by itself indicated for Crohn's disease, despite highly satisfactory control of his ankylosing spondylitis, strongly suggests a triggering effect of the drug. Interestingly, etanercept, a soluble receptor of TNF- $\alpha$ has been implicated in the onset of 6 cases of Crohn's disease [36-39] -3 of them in patients with ankylosing spondylitis [39]. The second case was a patient with very long-standing ankylosing spondylitis who developed palmo plantar psoriasis shortly after beginning a course of infliximab. There have been several reports in the medical literature of new-onset psoriasis or worsening of pre-existing skin diseases in patients treated with TNF- $\alpha$ inhibitors for psoriatic arthritis, rheumatoid arthritis, ankylosing spondylitis and inflammatory bowel disease. Interestingly, infliximab is efficacious in treating skin psoriasis. A great proportion of the patients described in the literature presented with palmo-plantar psoriasis, although all forms of psoriasis were described [2, 3, 530]. It has been suggested that palmo plantar psoriasis may be induced by an abnormal expression of TNF- $\alpha$ in the eccrine palmar sweat gland and duct [40]. Although TNF- $\alpha$ is a well-documented contributor to the psoriatic skin lesion, another important pathway for triggering common human autoimmune disease involves plasmacytoid dendritic cell precursors and type 1 interferon (INF) production. TNF- $\alpha$ regulates INF- $\alpha$ production and neutralization of endogenous TNF- $\alpha$ may promote INF- $\alpha$ production by plasmacytoid dendritic cells inducing psoriatic plaques [41]. Our third case was a woman with long-standing psoriasis who developed peripheral arthritis during treatment with infliximab. The differential diagnosis of this case includes infliximabinduced lupus and psoriatic arthritis. The fact that the arthritis subsequently responded to the infusion of infliximab and that the anti-dsDNA result was negative support the likelihood of the seronegative arthritis having been triggered by infliximab.

Another plausible explanation for the undesired evolution of our three cases may involve the effect of TNF- $\alpha$ antagonists on the risks of infection. TNF- $\alpha$ blockers have been implicated in the reactivation of a variety of infectious diseases, including mainly intracellular pathogens, such as Mycobacterium tuberculosis and others [42]. Immune activation by bacteria was shown to have a crucial role in the development of the disease in both reactive arthritis $(\operatorname{Re} A)$ and in the HLA-B27 transgenic rats model [43]. There is evidence that this is related to an abnormal persistence of intracellular pathogens, at least in ReA [31]. Recent studies indicate that other subtypes of SpA may also have an impairment of certain aspects of the innate immune defense, particularly with regard to the expression of scavenger receptors [44, 45]. However, whereas $\mathrm{SpA}$ has traditionally been associated with urogenital infection with chlamydia or gastrointestinal infections with Gram-negative pathogens, such as salmonella, shigella, campylobacter, and yersinia [46], treatment with anti-TNF- $\alpha$ blockers may affect the intestinal flora by inducing a change in the predominant manifestation of spondyloarthropathies.

Table 3. Outcome of Patients Who Developed Psoriasis After Treatment with TNF $\alpha$ Blocker

\begin{tabular}{|l|l|}
\hline \multicolumn{1}{|c|}{ TNF Blocker } & \multicolumn{1}{|c|}{ Outcome } \\
\hline \hline Infliximab (33 cases) & \\
Continued & $22 ; 17$ improved, 4 progressed, 2 UK \\
Discontinued & $20 ; 18$ improved, 0 progress, 2 UK \\
Switched to another TNF & $10 ;$ recurrence in 5 \\
Unknown & 4 \\
\hline Etanercept (16 cases ) & \\
Continued & $9 ; 8$ improved, 1 persisted \\
Discontinued & $4 ; 4$ improved \\
Switched to another TNF & 2, recurrence in 1 \\
Unknown & 4 UK \\
\hline Adalimumab & \\
Continued & $6 ; 3$ improved, 1 progressed, 1 UK \\
Discontinued & $9 ; 8$ improved, 1 progressed \\
Switched to another TNF & 3 swithched to another TNF, 1 recurrence \\
Unknown & 1 UK \\
\hline
\end{tabular}

In conclusion, in addition to the well-known autoimmune effects of anti-TNF- $\alpha$ therapy, our cases suggest the possibil- 
ity of other and untoward alterations of the course of spondyloarthropathies as a result of this treatment. In our patients, the trade-off was successful depression of one aspect of the disease at the expense of triggering a none less undesirable though occult facet of the spondyloarthropathic repertoire in an apparently predisposed patient.

\section{ACKNOWLEDGEMENT}

Esther Eshkol is thanked for editorial assistance.

\section{REFERENCES}

[1] Kalden JR. Emerging role of anti-tumor necrosis factor therapy in rheumatic diseases. Arthritis Res 2002; 4 Suppl 2: S34-40.

[2] Ramos-Casals M, Brito-Zer NP, Munoz S, et al. Autoimmune diseases induced by TNF-targeted therapies: analysis of 233 Cases. Medicine (Baltimore) 2007; 86: 242-51.

[3] De Gannes GC, Ghoreishi M, Pope J, et al. Psoriasis and pustular dermatitis triggered by TNF- $\alpha$ inhibitors in patients with rheumatologic conditions. Arch Dermatol 2007; 143: 223-31.

[4] Wright V, Moll JMH. Seronegative polyarthritis. North Holland Publishing Company, Amsterdam, New York, Oxford, 1976.

[5] Ubriani R, Van Voorhees AS. Onset of psoriasis during treatment with TNF- $\alpha$ antagonists: a report of 3 cases. Arch Dermatol 2007; 143(2): 270-2.

[6] Cohen JD, Bournerias I, Buffard V, et al. Psoriasis induced by tumor necrosis factor-alpha antagonist therapy: a case series. J Rheumatol 2007; 34(2): 380-5.

[7] Sari I, Akar S, Birlik M, Sis B, Onen F, Akkoc N. Anti-tumor necrosis factor-alpha-induced psoriasis. J Rheumatol 2006; 33(7): 1411-4.

[8] Verea MM, Del Pozo J, Yebra-Pimentel MT, Porta A, Fonseca E. Psoriasiform eruption induced by infliximab. Ann Pharmacother 2004; 38(1): 54-7.

[9] Beuthien W, Mellinghoff HU, Von Kempis J. Skin reaction to adalimumab. Arthritis Rheum 2004; 50(5): 1690-2.

[10] Sfikakis PP, Iliopoulos A, Elezoglu A, Kittas C, Stratigos A. Psoriasis induced by anti-tumor necrosis factor therapy: a paradoxical adverse reaction. Arthritis Rheum 2005; 52: 2513-8.

[11] Roux $\mathrm{CH}$, Brocq $\mathrm{O}$, Leccia $\mathrm{N}$, et al. New-onset psoriatic palmoplantaris pustulosis following infliximab therapy: a class effect? J Rheumatol 2007; 34: 247-9.

[12] Adams DR, Buckel T, Sceppa JA. Infliximab-associated new-onset psoriasis. J Drugs Dermatol 2006; 5: 178-9.

[13] Dereure O, Guillot B, Jorgensen C, Cohen JD, Combes B, Guilhou JJ. Psoriatic lesions induced by anti-tumor necrosis factor-alpha treatment: two cases. Br J Dermatol 2004; 151: 506-7.

[14] Flendrie M, Vissers WH, Creemers MC, de Jong EM, van de Kerkhof PC, Van Riel PL. Dermatological conditions during TNF- $\alpha$ blocking therapy in patients with rheumatoid arthritis: a prospective study. Arthritis Res Ther 2005; 7: 666-76.

[15] Grinblat B, Scheinberg M. Unexpected onset of psoriasis during infliximab treatment: comment on the article by Beuthien, et al. Arthritis Rheum 2005; 52(4): 1333-4.

[16] Haibel H, Spiller I, Strasser C. Unexpected new onset or exacerbating of psoriasis in treatment of active ankylosing spondylitis with TNF- $\alpha$ blocking agents [abstract]. Ann Rheum Dis 2004; 63(suppl): 405.

[17] Kary S, Worm M, Audring H, et al. New onset or exacerbation of psoriatic skin lesions in patients with definite rheumatoid arthritis receiving tumor necrosis factor alpha antagonists. Ann Rheum Dis 2006; 65: 405-7.

[18] Michaelsson G, Kajermo U, Michaelsson A, Hagforsen E. Infliximab can precipitate as well as worsen palmoplantar pustulosis: possible linkage to the expression of tumor necrosis factor-alpha in the normal palmar eccrine sweat duct? Br J Dermatol 2005; 153: $1243-4$.
[19] Peramiquel L, Puig L, Dalmau J, Ricart E, Roe E, Alomar A. Onset of flexural psoriasis during infliximab treatment for Crohn's disease. Clin Exp Dermatol 2005; 30: 713-4.

[20] Starmans-Kool MJ, Peeters HR, Houben HH. Pustular skin lesions in patients treated with infliximab: report of two cases. Rheumatol Int 2005; 25: 550-2.

[21] Thurber M, Feasel A, Stroehlein J, Hymes SR. Pustular psoriasis induced by infliximab. J Drugs Dermatol 2004; 3: 439-40.

[22] Richette P, Viguier M, Bachelez H, Bardin T. Psoriasis induced by anti-tumor necrosis factor therapy: a class effect? J Rheumatol 2007; 34(2): 438-9.

[23] Goiriz R, Dauden E, Perez-Gala G, Guhl G, Garcia-Diez A. Flare and change of psoriasis morphology during the course of treatment with tumor necrosis factor blockers. Clin Exp Dermatol 2006; 32: 176-9.

[24] Cavailhes A, Ingen-Housz-Oro S, Djennane S, et al. Survenue d'un psoriasis au cours d'un treatement par infliximab pour fasciite de Shulman. Ann Dermatol Venereol 2007; 134(4 Pt 1): 363-7.

[25] Volpe A, Caramaschi P, Carletto A, Pieropan S, Bambara LM, Biasi D. Psoriasis onset during infliximab treatment : description of two cases. Rheumatol Int 2006; 26: 1158-60.

[26] Papadavid E, Gazi S, Dalamaga M. Stavrianeas N, Ntelia V. Palmoplantar and scalp psoriasis occurring during anti-tumor necrosis factor $\alpha$ therapy: a case series of four patients and guidelines for management. J Eur Acad Dermatol Venerol 2007; 21: 380-382.

[27] Martinez-Moran C, Sanz-Munoz C, Morales-Callaghan AM, Torrero V, Miranda-Romero A. Pustular psoriasis induced by infliximab. J Eur Acad Dermatol Venerol 2007; 21: 1413-50

[28] Takahashi H, Hashimoto Y, Ishida-Yamamoto A, Ashida T, Kohgo Y, Iizuka H. Psoriasiform and pustular eruption induced by infliximab. J Dermatol 2007; 34(7): 468-72.

[29] Wegscheider BJ, El-Shabrawi L, Weger M, et al. Adverse skin reactions to infliximab in the treatment of intraocular inflammation. Eye 2007; 21: 547-9.

[30] Peek R, Scott-Jupp R, Strike H, Clinch J, Ramanan AV. Psoriasis after treatment of juvenile idiopathic arthritis with etanercept. Ann Rheum Dis 2006; 65(9): 1259.

[31] Elkayam O, Burke M, Vardinon N, et al. Autoantibodies profile of rheumatoid arthritis patients during treatment with infliximab. Autoimmunity 2005; 38: 155-60.

[32] Eriksson C, Engstrand S, Sundqvist KG, Rantapaa-Dahlqvist S. Autoantibody formation in patients with rheumatoid arthritis treated with anti-TNF- $\alpha$. Ann Rheum Dis 2005; 64: 403-7.

[33] De Rycke L, Kruithof E, Van Damme N, et al. Antinuclear antibodies following infliximab treatment in patients with rheumatoid arthritis or spondylarthropathy. Arthritis Rheum 2003; 48: 1015-23.

[34] Mielants H, Veys EM, Goemaere S, Goethals K, Cuvelier C, De Vos M. Gut inflammation in the spondyloarthropathies: clinical, radiologic, biologic and genetic features in relation to the type of histology. A prospective study. J Rheumatol 1991; 18: 1542-51

[35] Conti F, Borrelli O, Anania C, et al. Chronic intestinal inflammation and seronegative spondyloarthropathy in children. Dig Liver Dis 2005; 37: 761-7.

[36] Ruemmele FM, Prieur AM, Talbotec C, et al. Development of Crohn disease during anti-TNF- $\alpha$ therapy in a child with juvenile idiopathic arthritis. J Pediatr Gastroenterol Nutr 2004; 39: 203-6.

[37] Oh J, Arkfeld DG, Horwitz DA. Development of Crohn's disease in a patient taking etanercept. J Rheumatol 2005; 32: 52-3.

[38] Ahmad K, Rogers S. Development of Crohn disease in a patient on etanercept for psoriasis. Br J Dermatol 2007; 157(2): 396.

[39] Song IH, Appel H, Haibel H, et al. New onset of Crohn's disease during treatment of active ankylosing spondylitis with etanercept. J Rheumatol 2008; 35(3): 532-6.

[40] Michaelsson G, Kajermo U, Michaelsson A, Hagforsen E. Infliximab can precipitate as well as worsen palmoplantar pustulosis: possible linkage to the expression of tumor necrosis factor-alpha in the normal palmar eccrine sweat duct? Br J Dermatol 2005; 153: 1243-4. 
[41] Gilliet M, Conrad C, Geiges M, et al. Psoriasis triggered by tolllike receptor 7 agonist imiquimod in the presence of dermal plasmacytoid dendritic cell precursors. Arch Dermatol 2004; 140: $1490-5$.

[42] Strangfeld A, Listing J. Infection and musculoskeletal conditions: bacterial and opportunistic infections during anti-TNF therapy. Best Pract Res Clin Rheumatol 2006; 20: 1181-95.

[43] Breban M, Hacquard-Bouder C, Falgarone G. Animal models of HLA-B27-associated diseases. Curr Mol Med 2004; 4: 31-40.
[44] Kim TH, Uhm WS, Inman RD. Pathogenesis of ankylosing spondylitis and reactive arthritis. Curr Opin Rheumatol 2005; 17: 400-5.

[45] Baeten D, Demetter P, Cuvelier CA, et al. Macrophages expressing the scavenger receptor CD163: a link between immune alterations of the gut and synovial inflammation in spondyloarthropathy. J Pathol 2002; 196: 343-50.

[46] Seta N, Granfors K, Sahly H, et al. Expression of the host defence scavenger receptors in spondyloarthropathy. Arthritis Rheum 2001; 44: 931-9.

(C) Elkayam et al.; Licensee Bentham Open.

This is an open access article licensed under the terms of the Creative Commons Attribution Non-Commercial License (http://creativecommons.org/licenses/by$\mathrm{nc} / 3.0 /$ ) which permits unrestricted, non-commercial use, distribution and reproduction in any medium, provided the work is properly cited. 